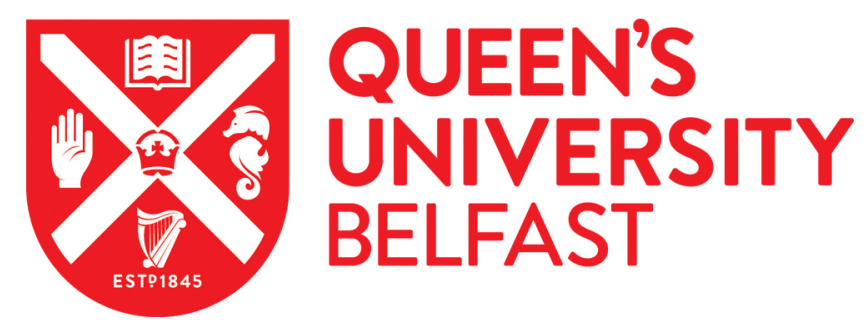

\title{
IMPACT OF DNA REPAIR, FOLATE AND GLUTATHIONE GENE POLYMORPHISMS ON RISK OF NON-SMALL CELL LUNG CANCER
}

Perez Ramirez, C., Canadas Garre, M. L., Alnatsha, A., Villar, E., Delgado, J. R., Calleja Hernandez, M. A., \& Faus-Dáder, M. J. (2017). IMPACT OF DNA REPAIR, FOLATE AND GLUTATHIONE GENE

POLYMORPHISMS ON RISK OF NON-SMALL CELL LUNG CANCER. Pathology, research and practice. https://doi.org/10.1016/j.prp.2017.11.015

Published in:

Pathology, research and practice

Document Version:

Peer reviewed version

Queen's University Belfast - Research Portal:

Link to publication record in Queen's University Belfast Research Portal

\section{Publisher rights}

Copyright 2017 Elsevier.

This manuscript is distributed under a Creative Commons Attribution-NonCommercial-NoDerivs License

(https://creativecommons.org/licenses/by-nc-nd/4.0/), which permits distribution and reproduction for non-commercial purposes, provided the author and source are cited.

\section{General rights}

Copyright for the publications made accessible via the Queen's University Belfast Research Portal is retained by the author(s) and / or other copyright owners and it is a condition of accessing these publications that users recognise and abide by the legal requirements associated with these rights.

\section{Take down policy}

The Research Portal is Queen's institutional repository that provides access to Queen's research output. Every effort has been made to ensure that content in the Research Portal does not infringe any person's rights, or applicable UK laws. If you discover content in the

Research Portal that you believe breaches copyright or violates any law, please contact openaccess@qub.ac.uk. 


\section{Accepted Manuscript}

Title: IMPACT OF DNA REPAIR, FOLATE AND GLUTATHIONE GENE POLYMORPHISMS ON RISK OF NON-SMALL CELL LUNG CANCER.

Authors: Cristina Pérez-Ramírez, Marisa Cañadas-Garre, Ahmed Alnatsha, Eduardo Villar, Juan Ramón Delgado,

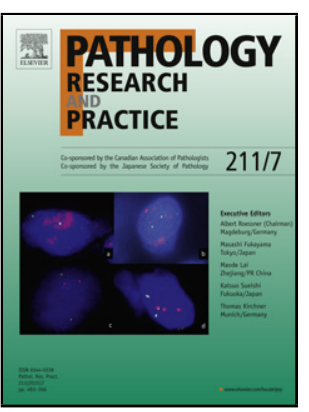

Miguel Ángel Calleja-Hernández, María José Faus-Dáder

PII:

S0344-0338(17)30895-6

DOI:

Reference: https://doi.org/10.1016/j.prp.2017.11.015

PRP 51949

To appear in:

Received date:

5-9-2017

Revised date:

Accepted date:

Please cite this article as: Cristina Pérez-Ramírez, Marisa Cañadas-Garre, Ahmed Alnatsha, Eduardo Villar, Juan Ramón Delgado, Miguel Ángel Calleja-Hernández, María José Faus-Dáder, IMPACT OF DNA REPAIR, FOLATE AND GLUTATHIONE GENE POLYMORPHISMS ON RISK OF NON-SMALL CELL LUNG CANCER., Pathology - Research and Practice https://doi.org/10.1016/j.prp.2017.11.015

This is a PDF file of an unedited manuscript that has been accepted for publication. As a service to our customers we are providing this early version of the manuscript. The manuscript will undergo copyediting, typesetting, and review of the resulting proof before it is published in its final form. Please note that during the production process errors may be discovered which could affect the content, and all legal disclaimers that apply to the journal pertain. 


\section{TITLE}

IMPACT OF DNA REPAIR, FOLATE AND GLUTATHIONE GENE POLYMORPHISMS ON RISK OF NON-SMALL CELL LUNG CANCER.

\section{AUTHORS:}

Cristina Pérez-Ramírez ${ }^{1,2}$, Marisa Cañadas-Garre ${ }^{1,3}$, Ahmed Alnatsha ${ }^{1,3}$, Eduardo Villar ${ }^{4}$, Juan Ramón Delgado ${ }^{5}$, Miguel Ángel Calleja-Hernández ${ }^{1,6}$, María José Faus-Dáder².

\section{Author for correspondence}

\section{Marisa Cañadas-Garre}

Nephrology Research Group

Centre for Public Health

Queen's University of Belfast

c/o Regional Genetics Centre, Level A, Tower Block

Belfast City Hospital, Lisburn Road, Belfast, BT9 7AB

Telephone: 02890638460

Fax: 02890235900

http://go.qub.ac.uk/Marisa

E-mail: marisacgarre@gmail.com

\section{Affiliations}

\section{Pharmacogenetics Unit}

UGC Provincial de Farmacia de Granada

Instituto de Investigación Biosanitaria de Granada

Complejo Hospitalario Universitario de Granada

Avda. Fuerzas Armadas, 2

Telephone: $\quad+34958020108$

Fax: $\quad+34901021804$

2 Department of Biochemistry

Faculty of Pharmacy

University of Granada

Campus Universitario de Cartuja, s/n

18071 Granada, Spain

Telephone: +34958243838

$3 \quad$ Nephrology Research Group

Centre for Public Health

Queen's University of Belfast

c/o Regional Genetics Centre, Level A, Tower Block

Belfast City Hospital, Lisburn Road, Belfast, BT9 7AB

Telephone: 02890638460

Fax: 02890235900

3 Department of Molecular Medicine

Faculty of Medicine

University of Tübingen

Geissweg 5

72076 Tübingen

Telephone: $\quad$ +4907071 29-73682 
UGC Anatomía Patológica

Instituto de Investigación Biosanitaria de Granada

Complejo Hospitalario Universitario de Granada

Avda. Fuerzas Armadas, 2

18014 Granada, Spain

Telephone: +34958020374

5 Medical Oncology Service

UGC Oncología Médica

Instituto de Investigación Biosanitaria de Granada

Complejo Hospitalario Universitario de Granada

Avda. Fuerzas Armadas, 2

18014 Granada, Spain

Telephone: +34958020346

6

Department of Pharmacology

Faculty of Pharmacy

University of Granada

Campus Universitario de Cartuja, s/n

18071 Granada, Spain

Telephone: +34958243538

Mails

Cristina Pérez-Ramírez

cperezramirez87@gmail.com

Ahmed Alnatsha

r.j.b-man@hotmail.com

Marisa Cañadas-Garre

marisacgarre@gmail.com

Eduardo Villar

eduardovillar6@gmail.com

Juan Ramón Delgado

juanramondelgado@gmail.com

María José Faus-Dáder mfaus@ugr.es

Miguel Ángel Calleja Hernández

mangel.calleja.sspa@juntadeandalucia.es

Keywords:

NON-SMALL CELL LUNG CANCER

RISK

POLYMORPHISMS

DNA REPAIR PATHWAY

FOLATE METABOLISM PATHWAY

GLUTATHIONE METABOLISM PATHWAY

WORD COUNT (excluding references and figure legends):

Abstract: $\quad 98$ words

Main Text: 2801 words

FUNDING

This work was partly supported by a contract for Marisa Cañadas-Garre (Técnicos de Apoyo Subprogram. CA12/00097) from Instituto de Salud Carlos III, Ministerio de Economía y Competitividad and a research grant for Cristina Pérez-Ramírez (FPU12/04722), from Ministerio de Educación, Cultura y Deporte. The Hospital Universitario Virgen de las Nieves Biobank was supported by grants cofinanced by FEDER funds (EU) from the Instituto de Salud Carlos III (PT13/0010/0039). 


\section{CONFLICT OF INTEREST}

The authors declare that there is not conflict of interest that could be perceived as prejudicing the impartiality of the research reported and there is not any competing financial interest in relation to the work described in this article.

\section{ABSTRACT}

Lung cancer, particularly non-small cell lung cancer (NSCLC) subtype, is the leading cause of cancer-related death related worldwide. Numerous gene polymorphisms in DNA repair, folate and glutathione pathways have been associated with susceptibility of NSCLC. We conducted this study to evaluate the effects of ERCC1, ERCC2, ERCC5, XRCC1, XRCC3, MTHFR, MTR, MTHFD1, SLC19A1 and GSTP1 gene polymorphisms on risk of NSCLC.

No association between these gene polymorphisms and susceptibility of NSCLC were found in our patients, suggesting that genetic variations in genes involved in DNA repair, folate and glutathione metabolism pathways may not influence the risk of NSCLC.

\section{INTRODUCTION}

Lung cancer is one of the most common and serious types of cancer in the world, being the main cause of cancer mortality worldwide [1]. The incidence of lung cancer is approximately $14 \%$ in both genders (second after prostate cancer in men and breast cancer in women)[1]. The latest statistics of cancer in the United States have estimated 224,300 new cases and 158,000 deaths in 2016 [1].

Lung cancer is classified into two major types: small cell lung cancer (SCLC) and nonsmall cell lung cancer (NSCLC), which is divided into three types: squamous cell carcinoma, adenocarcinoma and large cell carcinoma [2, 3]. NSCLC cases account for approximately $80 \%$ of all lung cancers [4-6]. Most patients are diagnosed in older age

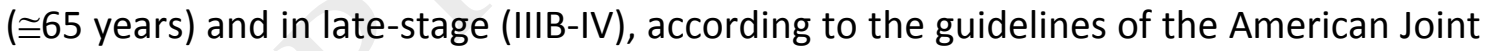
Committee on Cancer (AJCC) showing low overall survival rates at 5 years $(5 \%$ for IIIB and $1 \%$ for IV stages) $[4,6,7]$.

Smoking is by far the biggest cause of lung cancer (It causes more than $80 \%$ of the cases), although different genetic factors may have an increased risk of lung cancer. Recently, genetic factors, such as single nucleotide polymorphisms (SNPs) have showed a strong association with risk of lung cancer $[2,8]$. One of the most studied pathway is repaired DNA, which plays an essential role on carcinogenesis [9]. The DNA may be damaged through many factors such as tobacco smoke, dietary factors, infectious agents and radiation [10]. These modifications may introduce errors during the replication and the transcription, that induce dysfunction of repair DNA machinery [10]. The leading systems involved in repairing DNA damage are nucleotide-excision repair (NER), base excision repair (BER) and double-strand break repair (DSB) [11, 12]. NER pathway is involved in repairing helix-distorting DNA lesions through ERCC1 (excision repair cross-complementing group 1) and ERCC2 (excision repair cross- 
complementation group 2), ERCC5 (excision repair cross-complementation group 5) genes [11]. Defective repair in Chinese hamster cells 1 (XRCC1) is the key gene in BER pathway, that removes damaged DNA by small, non-helix-distorting lesions [13]. Most serious modifications, such as deletions and chromosomal aberrations, are repaired by DBS pathway, through $\mathrm{X}$-ray repair complementing defective repair in Chinese hamster cells 3 (XRCC3) gene [14]. Therefore, polymorphisms in these genes may play a crucial role on development of lung cancer [15-23].

Other pathways involved in risk of lung cancer are folate and glutathione metabolism. Folate metabolism is involved in DNA synthesis and DNA methylation [24]. The MTHFR (methylenetetrahydrofolate reductase), MTHFD1 (methylenetetrahydrofolate dehydrogenase, cyclohydrolase and formyltetrahydrofolate synthetase 1) and MTR (5methyltetrahydrofolate-homocysteine methyltransferase) enzymes are involved in methylation of DNA. Genetic alterations in these genes are associated with aberrant methylation of tumor-suppressor genes and hypomethylation of proto-oncogenes [25]. SLC19A1 (reduced folate carrier 1) is also one of the key genes in folate pathway, because of its function as folate transporter [26]. In fact, polymorphisms in this gene are related with DNA synthesis disorders that lead to genomic instability [27]. Therefore, genetic variations in these genes may lead to alteration in the DNA methylation and synthesis, inducing tumorigenesis [28-32]. The damage caused by cytotoxic and carcinogenic agents is catalysed by glutathione transferases enzymes, such as GSTP1 (glutathione S-transferase P1) [33]. This gene, which is located in chromosome 11q13, is mainly expressed in lung tissues and exerts an important function on inhaled carcinogens, such as tobacco carcinogens [34-37]. Thus, polymorphisms in GSTP1 are believed to be associated with risk of lung cancer $[37,38]$.

Based on above, we conducted this study to evaluate the effects of ERCC1, ERCC2, ERCC5, XRCC1, XRCC3, MTHFR, MTR, MTHFD1, SLC19A1 and GSTP1 gene polymorphisms on risk of NSCLC. To prepare this paper a thorough search was made. These SNPs were selected based on their effects on gene or protein function/expression, etc confirmed by data from biochemical/function studies

\section{MATERIAL AND METHODS}

A retrospective case-control study was performed.

\subsection{Study Subjects}

This study involved 174 NSCLC cases and 298 controls of South Spanish Caucasian origin. The eligible cases included patients histologically or cytologically diagnosed as NSCLC between 2003-2015 at the University Hospital Virgen de las Nieves, Granada, Spain. The participants of control group were Caucasian individuals older than 18 years from the same geographic area (South Spain), with available follow-up records at the same hospital. Individuals with prior cancer history were excluded from this study. The subjects enrolled in this case-control study provided their written informed consent form for blood/saliva sample collection and donation to the Biobank. The identification of samples was based on non-patient identifiers and they were treated confidentially.

This case-control study was conducted in accordance with the declaration of Helsinki under the approval of the Ethics and Research Committee of the Sistema Sanitario Público de Andalucía Biobank. 


\subsection{Sociodemographic and clinical variables}

Sociodemographic (gender, smoking status and age at diagnosis) and clinical variables (previous lung disease) were collected from clinical records. Smoking status was classified as current-smokers, former-smokers and never-smokers. Individuals were categorized as never smokers if they smoked less than 100 cigarettes; former smokers had quit at least 5 years prior to the recruitment and current smokers continued to smoke or quit less than 5 years prior to the recruitment. Tumor histology and stage were also collected for the case group. Tumor staging was categorized according to the guidelines of the American Joint Committee on Cancer (AJCC) [39].

\subsection{Genetic variables}

\subsubsection{DNA isolation}

DNA samples isolated from blood or saliva were obtained from the Hospital Universitario Virgen de las Nieves Biobank, a part of the Sistema Sanitario Público de Andalucía Biobank.

\subsubsection{Detection of gene polymorphisms}

ERCC1 ( $r$ 11615), ERCC1 (rs3212986), ERCC2 ( $r$ 13181), ERCC2 ( $r$ 1799793), ERCC2 (rs50872), ERCC2 (rs238405), ERCC2 (rs238416), ERCC5 (rs104778), ERCC5 (rs17655), ERCC5 (rs2296147), ERCC5 (rs2094258), ERCC5 (rs873601), XRCC1 (rs1799782), XRCC1 ( $r$ 25487), XRCC3 (rs861539), MTHFR (rs1801131), MTHFR ( $r$ 1801133), MTHFD1 (rs2236225), MTR (rs1805087), SLC19A1 (rs1051266) and GSTP1 (rs1695) gene polymorphisms were analyzed by Real-Time PCR using TaqMan ${ }^{\circledR}$ probes. Genotyping methodology was previously described [40]. Briefly, the presence of wild-type and variant alleles was defined by comparing the relative end-point fluorescence created by the degradation of each fluorescently labelled TaqMan ${ }^{\circledR}$ probe (FAM/VIC). Allelic calls were determined using StepOne ${ }^{\mathrm{TM}}$ Software v2.3. To evaluate internal consistency, $86 \%$ of samples were duplicated, and $15 \%$ of the results were confirmed by sequencing analysis.

\subsection{Statistical Analysis}

Descriptive analysis was performed using R 3.0.1 [49]. Quantitative data were expressed as the mean ( \pm standard deviation) for normally-distributed variables or medians and percentiles (25 and 75) for non-normal distributed variables. The ShapiroWilks test was performed to assess normality.

Hardy-Weinberg equilibrium and pairwise haplotype frequencies were estimated, and Lewontin's D prime ( $\left.D^{\prime}\right)$ and the linkage disequilibrium coefficient ( $r 2$ ) were calculated. The bivariate association between NSCLC risk and polymorphisms was assessed for multiple models (genotypic, additive, allelic, dominant and recessive), using the Pearson's chi-square and Fisher's exact test, and evaluated by odds ratio (OR) and their corresponding $95 \%$ confidence intervals $(\mathrm{Cl})$. The models were defined as follows: allelic ( $D$ vs d), dominant ((DD, Dd) vs dd), recessive (DD vs (Dd, dd)) and genotypic (DD vs $D d$ vs $d d$ ) and additive, being $D$ the minor allele and $d$ the major allele. Permutation analysis (EMP1) was used for multiple comparisons, that compares the observed statistic with 100,000 statistics obtained in permutations in the correspondent SNP. To control the family-wise error rate when testing multiple SNPs, the observed statistic 
was compared with the maximum of permuted statistics over all SNPs (EMP2). Unconditional multiple logistic regression models (genotypic, dominant and recessive) were considered to determine the influence of potential confounding variables on the risk of lung cancer. All tests were two-sided with a significant level of $p<0.05$, and were performed using the free, open-source whole genome association analysis toolset $R$ 3.2.2 or PLINK [41, 42].

\section{RESULTS}

\subsection{Patients characteristics}

Clinical, sociodemographic and pathologic characteristics of the 174 NSCLC patients and 298 controls are described in Table 1 . The patients had an average age of $60.67 \pm 10.58$ and consisted of 109 adenocarcinomas (109/174; 62.64\%) and 61 squamous cell carcinoma $(61 / 174 ; 35.06 \%)$, most of them with advanced stage $(119 / 174 ; 68.39 \%)$. The median age for the controls was $72.90[67,80]$, and the proportion of current smokers was lower in this group $\left(p<2.2 \cdot 10^{-16}\right.$; Table 1$)$. Distribution of previous lung disease was similar in both groups $(p=0.618$; Table 1$)$.

\subsection{Genotype distribution}

Genotype frequencies were in agreement with the values expected under the HardyWeinberg equilibrium model. Linkage disequilibrium values $D^{\prime}$ and $r^{2}$ are shown in Table S1. No linkage disequilibrium was showed in any case. All SNPs presented minor allele frequencies over $1 \%$, therefore none of them were excluded from the analysis (Table S2).

\subsection{Influence of gene polymorphisms on risk of NSCLC}

The bivariate analysis was performed in multiple models: genotypic, additive, allelic, dominant and recessive (Table 2). ERCC5 rs104778 was the only gene polymorphism associated with risk of NSCLC in the recessive model. Carriers of the CC genotype were in higher risk of NSCLC compared with those with T allele $(p=0.04507$; OR $=1.624$; $\left.\mathrm{Cl}_{95 \%}=1.005,2.617\right)$. This significant association was confirmed after adjusting by permutation analysis (Table 3 ). However, no significant association was found in the logistic regression analysis (Table 4). Similarly, no significant differences for other gene polymorphisms (rs11615, rs3212986, rs13181, rs1799793, rs50872, rs238405, rs238416, rs17655, rs2296147, rs2094258, rs873601, rs1799782, rs25487, rs861539, rs1695, rs1801131, rs1801133, rs2236225, rs1805087 and rs1051266) in allele or genotype frequencies were shown between NSCLC patients and controls (Table 2).

\section{DISCUSSION}

Smoking is the main risk factor for lung cancer development. However, genetic alterations in genes involved in DNA repair pathway, folate and glutathione metabolisms have been reported to play a crucial role in risk of NSCLC. We conducted this study to evaluate the effect of variants in genes involved in DNA repair, folate and glutathione metabolism pathways on NSCLC risk.

DNA repair pathway plays a crucial function in protecting against gene mutation caused by carcinogenesis. ERCC1 is the key enzyme in the NER pathway [43]. ERCC1 rs11615 and rs3212986 gene polymorphisms are the most studied [20]. A metaanalysis, which evaluated 11 studies from Caucasian and Asian population (5009 
cases/5542 controls) reported that in the overall population individuals carrying at least one C allele of ERCC1 rs11615 gene polymorphism were in lower risk of NSCLC

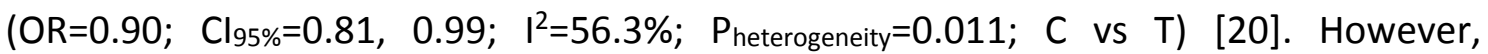
stratified analysis by ethnicity showed no significant association between rs11615 and lung cancer risk in either Asian or Caucasian subgroups [20]. Similarly, a meta-analysis that included 3 studies with 3060 cases and 2729 controls from Caucasian and Asian population failed to find an association between ERCC1 rs3212986 and NSCLC incidence $\left(\mathrm{OR}=1.03 ; \mathrm{Cl}_{95 \%}=0.95,1.11 ; \mathrm{I}^{2}=0 \%\right.$; $\mathrm{P}_{\text {heterogeneity }}=0.746 ; \mathrm{A}$ vs $\mathrm{C}$ ) [20]. In our study, we did not find a significant association between neither of those gene polymorphisms and risk of NSCLC, which was consistent with the results of both metaanalyses in Caucasian population. ERCC2 also plays an essential function on DNA repair pathway [44]. Numerous SNPs in ERCC2 gene have been described, being ERCC2 rs13181 and rs1799793 the most investigated [16, 21]. A meta-analysis comprising 28 studies, with 23370 subjects (10242 cases/13128 controls) from Caucasian and Asian origin has recently evaluated the role of ERCC2 Lys751GIn polymorphism in risk of lung cancer [21]. This meta-analysis presented the C allele of ERCC2 rs13181 as an increased risk factor for developing lung cancer, both in overall population (OR=1.186; $\mathrm{Cl}_{95 \%}=1.089,1.292$; Pheterogeneity $=0.000 ; \mathrm{A}$ vs GG) and subgroup analysis (Caucasian: $\mathrm{OR}=1.113 ; \mathrm{Cl}_{95 \%}=1.033,1.199 ; \mathrm{P}_{\text {heterogeneity }}=0.005 ; \mathrm{C}$ vs $\mathrm{AA}$ and Asian: OR=1.252; $\mathrm{Cl}_{95 \%=1.015,1.544 ;}$ P heterogeneity=0.238; C vs AA) [21]. For ERCC2 rs1799793, a metaanalysis analyzed a total of 17 studies involving 5820 lung cancer cases and 7378 controls showed that Asian and smoking carriers of ERCC2 rs1799793-A allele were in higher risk for developing NSCLC (OR=1.84; $\mathrm{Cl}_{95 \%}=1.31,2.27$; $\mathrm{P}_{\text {heterogeneity }}=0.238$; A vs GG and $\mathrm{OR}=1.56 ; \mathrm{Cl}_{95 \%}=1.31,1.87$; $P_{\text {heterogeneity }}=0.528$; $\mathrm{A}$ vs GG, respectively) [16]. However, in our study we did not find a significant association between ERCC2 rs13181 and rs1799793 gene polymorphisms and risk of NSCLC. We also evaluated the role of other ERCC2 gene polymorphisms (rs50872, rs238405 and rs238416) on risk of NSCLC, but no significant association was detected either. To date, no other studies have explored the association between these polymorphisms and NSCLC incidence. Other gene with an important role on DNA repair pathway is ERCC5 [45]. ERCC5 rs17655 and rs104778 gene polymorphisms are the most studied [17]. Recently, a meta-analysis has evaluated the effect of ERCC5 rs17655 on risk of lung cancer [17, 18, 22]. This metaanalysis gathered 6 studies from Caucasian and Asian population including a total of 2293 patients and 2586 controls, and reported higher risk of NSCLC for CC genotype

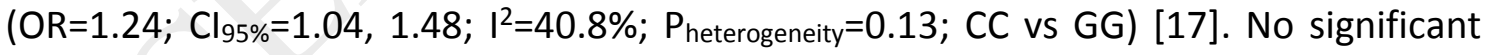
association was observed in our patients between ERCC5 rs17655 and risk of NSCLC. The ERCC5 rs104778-CC genotype has been associated with a significantly increased risk of lung cancer $\left(\mathrm{OR}=1.79, \mathrm{Cl}_{95 \%}=1.19,2.63\right.$; $\mathrm{CC}$ vs TT) in Caucasian population but not in Asian (OR=1.23, $\mathrm{Cl}_{95 \%}=0.53,2.85 ; \mathrm{CC}$ vs TT) $[18,22]$. In our study, the recessive model was in consonance with these results. However, the logistic regression analysis did not show significant association. We also analyzed ERCC5 rs2296147, rs2094258 and rs873601 gene polymorphisms, but they did not show any effect on NSCLC risk. To date, no other studies have evaluated the role of these gene polymorphisms on risk of NSCLC. XRCC1 is the main gene in DSB pathway [13]. XRCC1 rs1799782 and rs25487 gene polymorphisms are the most studied [15, 23]. For XRCC1 rs1799782 polymorphism, a meta-analysis, which comprised a total of 16 studies with 4848 cases and 6592 controls from Caucasian and Asian origin, has reported that individuals 
carrying the AG genotype had lower risk of lung cancer $\left(\mathrm{OR}=0.88 ; \mathrm{Cl}_{95 \%}=0.79-0.97\right.$; $P_{\text {heterogeneity }}=0.37 ; A G$ vs $A A$ ) [15]. No other associations were significant (OR=1.07;

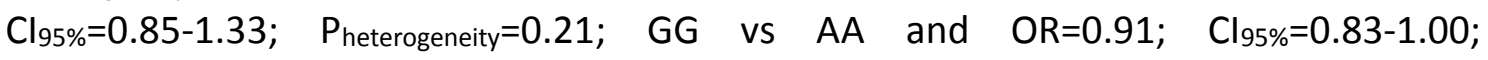
$P_{\text {heterogeneity }}=0.21 ; G$ vs AA) [15]. Recently, a study that recruited 222 healthy controls and 102 patients with lung cancer from Caucasian origin has described increased risk for lung cancer for the GG genotype (OR=10.667; $\mathrm{Cl}_{95 \%}=1.309-86.933 ; \mathrm{p}=0.007$; $\mathrm{GG}$ vs A)[23]. The XRCC1 rs25487-A allele was proposed as protective for lung cancer in a meta-analysis that included a total of 30 studies with 10214 cases and 12599 controls (OR=0.86; $\mathrm{Cl}_{95 \%=0.77-0.97 ;}$ Pheterogeneity=0.08; G vs AA) [15]. However, in our study, no significant association for none of these gene polymorphisms was found. XRCC3 is the most important gene in DBS pathway $[14,46]$. XRCC3 rs861539 gene polymorphism is the most relevant [19]. A recent meta-analysis has been performed to evaluate its role on risk of lung cancer [19]. A total of 21 studies, including 6880 lung cancer cases and 8329 controls from Caucasian and Asian population, were included, but no significant association was found (OR=1.02; $\mathrm{Cl}_{95 \%}=0.91-1.13 ; \mathrm{I}^{2}=59 \%$; $\mathrm{P}_{\text {heterogeneity }}=0.0006$; $\mathrm{T}$ vs C) [19]. Our study is in consonance with this result, since we did not find significant association between XRCC3 rs861539 and risk of NSCLC.

Other pathways involved in risk of NSCLC are folate and glutathione metabolism. Several proteins are crucial in folate metabolisms such as MTHFR, MTHFD1, MTR and SLC19A1 and have been found to be associated with risk of lung cancer [28-32]. Two polymorphisms in MTHFR, rs1801131 and rs1801133 are the most studied [29, 30]. For MTHFR rs1801131, a meta-analysis that included a total of 7 studies with 5087 cases and 6232 controls from Asian origin, reported no significant association with risk of

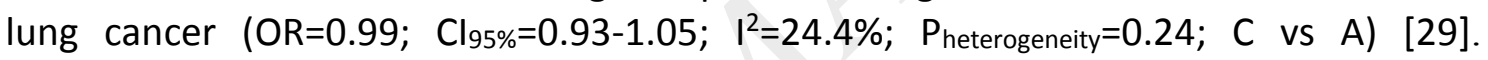
Similarly, we did not found a significant association between MTHFR rs1801131 and risk of lung cancer. The MTHFR rs1801133-TT genotype has been associated with higher risk of lung cancer in a meta-analysis that comprised a total of 19 studies with 11644 cases and 12024 controls from Caucasian and Asian population (OR=1.19; $\mathrm{Cl}_{95 \%}=1.03-1.37 ; \mathrm{I}^{2}=61 \%$; $P_{\text {heterogeneity }}=0.0003 ;$ TT vs C) [30]. However, we did not find a significant association between MTHFR rs1801133 and risk of lung cancer. One of the most investigated polymorphisms in MTHFD1 gene is rs2236225. The importance of MTHFD1 rs2236225 has been evaluated in a previous study composed by 500 lung cancer patients and 517 controls from Asian origin [31]. Although the T allele of rs2236225 polymorphism in MTHFD1 was associated with lower risk of lung cancer [31], this effect was not confirmed in our study (OR=0.76; $\mathrm{Cl}_{95 \%}=0.59-0.99 ; \mathrm{T}$ vs CC). The role of SLC19A1 and MTR gene polymorphisms on risk of lung cancer has also been previously studied. In particular, SLC19A1 rs1051266 and MTR rs1805087 have been investigated, but no significant results have been reported [28, 31, 32]. Thus, our results were in agreement with these previous studies. GSTP1 is the key enzyme involved in glutathione metabolism [47]. The most studied polymorphism in GSTP1 gene is rs1695 [37, 38]. A meta-analysis that enrolled 13 studies with 2026 cases and 2451 controls from Asian origin has reported higher risk of lung cancer for GSTP1

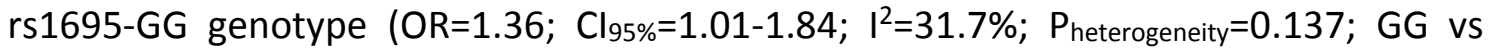
AA)[38]. However, this effect has not been confirmed in Caucasian population. A metaanalysis, which included a total of 14 studies with 2054 case series and 5525 controls from Caucasian origin has reported no association between GSTP1 rs1695-G allele/GG genotype and susceptibility of squamous cell carcinoma, a subtype of NSCLC (OR=1.06; 
$\mathrm{Cl}_{95 \%}=0.93-1.21 ; \quad \mathrm{I}^{2}=53 \% ; \mathrm{P}_{\text {heterogeneity }}=0.01 ; \mathrm{G}$ vs $\mathrm{A}$ and $\mathrm{OR}=1.20 ; \mathrm{Cl}_{95 \%}=0.94-1.53$; $I^{2}=37 \%$; $P$ heterogeneity $=0.09$ ) [37]. These results in Caucasian population are in accordance with our study [37].

The main limitation of this study was the limited size of the sample compared to other studies, particularly in the cases group. This may have led to a lack of power to detect associations in some polymorphisms. The strengths of our study include a very homogeneous cohort of cases, only composed by NSCLC patients diagnosed by the same team of pathologists, recruited from the same geographic area, which increases their uniformity.

In summary, we investigated the effect of ERCC1 (rs11615), ERCC1 (rs3212986), ERCC2 ( rs13181), ERCC2 (rs1799793), ERCC2 (rs50872), ERCC2 (rs238405), ERCC2 (rs238416), ERCC5 (rs17655), ERCC5 (rs104778), ERCC5 (rs2296147), ERCC5 ( $r$ 2094258), ERCC5 (rs873601), XRCC1 (rs1799782), XRCC1 (rs25487), XRCC3 (rs861539), MTHFR (rs1801131), MTHFR (rs1801133), MTHFD1 (rs2236225), MTR (rs1805087), SLC19A1 (rs1051266) and GSTP1 (rs1695) gene polymorphisms on NSCLC risk. The results showed no association between these gene polymorphisms and susceptibility of NSCLC, suggesting that genetic variations in genes involved in DNA repair, folate and glutathione metabolism pathways may not influence the risk of NSCLC.

\section{CONCLUSIONS \& FUTURE PERSPECTIVE}

This study failed to identify an association between ERCC1, ERCC2, ERCC5, XRCC1, XRCC3, MTHFR, MTR, MTHFD1, SLC19A1 and GSTP1 gene polymorphisms and susceptibility to NSCLC. Further studies including a wider spectrum of gene polymorphisms and larger samples will be required to definitely rule out the influence of these genes on risk of NSCLC.

\section{EXECUTIVE SUMMARY}

Relationship between gene polymorphisms in DNA repair, folate and glutathione pathways and NSCLC risk.

- DNA repair genes such as ERCC1, ERCC2 and XRCC1 play a crucial role on development of lung cancer.

- Polymorphisms in folate metabolism are related with DNA synthesis disorders that lead to genomic instability and subsequently cancer susceptibility.

- GSTP1 is expressed mainly in lung tissues and exerts an important function on inhaled carcinogens, such as tobacco carcinogens. Thus, polymorphisms in this gene are believed to be associated with risk of lung cancer.

\section{Conclusions}

Genetic variations in genes involved in DNA repair, folate and glutathione metabolism pathways may not influence the risk of NSCLC.

\section{ACKNOWLEDGMENTS}

The results of this investigation are part of the doctoral thesis presented by Cristina Pérez-Ramírez at the University of Granada, developed within the doctoral program "Medicina Clínica y Salud Pública". 


\section{AUTHOR CONTRIBUTIONS}

Cristina Pérez-Ramírez revised the bibliography and wrote the protocol for this study and acted as the primary lead in the conception, design and implementation of the project, data collection, molecular analysis, statistical analysis and interpretation, as well as all aspects of the development and writing of the article and responses to internal and external reviewers.

Marisa Cañadas-Garre, PhD, supervised the planning of the study protocol and contributed to the conception, design and implementation of the project, statistical analysis and interpretation as well as all aspects of the development and writing of the article and responses to internal and external reviewers.

Ahmed Alnatsha performed literature review, molecular analysis and interpretation, clinical data collection and interpretation and collaborated in drafting the manuscript.

Eduardo Villar, MD, PhD, performed molecular and pathological analysis and interpretation, clinical data collection and interpretation and collaborated in drafting the manuscript.

Juan Ramón Delgado, MD participated in the clinical data collection and interpretation, and provided clinical guidance and feedback for this study and critical review of the manuscript.

María José Faus-Dáder, PhD and Miguel Ángel Calleja-Hernández, PhD, participated in article selection, study quality assessment, critical review of the manuscript and contributed to revisions and responses to internal and external reviewers.

\section{REFERENCES}

1. Siegel RL, Miller KD, Jemal A: Cancer statistics, 2016. CA: a cancer journal for clinicians 66(1), 7-30 (2016).

2. Marshall AL, Christiani DC: Genetic susceptibility to lung cancer-light at the end of the tunnel? Carcinogenesis 34(3), 487-502 (2013).

3. Ansari J, Shackelford RE, El-Osta H: Epigenetics in non-small cell lung cancer: from basics to therapeutics. Translational lung cancer research 5(2), 155-171 (2016).

4. Edge S, Byrd, D.R., Compton, C.C., Fritz, A.G., Greene, F.L., Trotti, A: AJCC Cancer Staging Manual. (7th). 649 (2010).

5. Herbst Rs HJ, Lippman Sm.: Lung cancer. N Engl J Med. 359(13), 1367-1380 (2008).

6. Molina JR, Yang P, Cassivi SD, Schild SE, Adjei AA: Non-small cell lung cancer: epidemiology, risk factors, treatment, and survivorship. Mayo Clinic proceedings 83(5), 584-594 (2008).

7. Herbst RS, Heymach JV, Lippman SM: Lung cancer. The New England journal of medicine 359(13), 1367-1380 (2008).

8. Risch A, Plass C: Lung cancer epigenetics and genetics. International Journal of Cancer 123(1), 1-7 (2008). 
9. Dixon K, Kopras E: Genetic alterations and DNA repair in human carcinogenesis. Semin Cancer Biol 14(6), 441-448 (2004).

10. Kiyohara C, Yoshimasu K: Genetic polymorphisms in the nucleotide excision repair pathway and lung cancer risk: a meta-analysis. International journal of medical sciences 4(2), 59-71 (2007).

11. Sancar A: DNA repair in humans. Annu Rev Genet 29, 69-105 (1995).

12. Garcia-Campelo R, Alonso-Curbera G, Anton Aparicio LM, Rosell R: Pharmacogenomics in lung cancer: an analysis of DNA repair gene expression in patients treated with platinum-based chemotherapy. Expert Opin Pharmacother 6(12), 2015-2026 (2005).

13. Whitehouse $\mathrm{CJ}$, Taylor RM, Thistlethwaite A et al.: XRCC1 stimulates human polynucleotide kinase activity at damaged DNA termini and accelerates DNA single-strand break repair. Cell 104(1), 107-117 (2001).

14. Brenneman MA, Wagener BM, Miller CA, Allen C, Nickoloff JA: XRCC3 controls the fidelity of homologous recombination: roles for XRCC3 in late stages of recombination. Molecular cell 10(2), 387-395 (2002).

15. Wang $\mathrm{Y}$, Yang $\mathrm{H}$, Li $\mathrm{H}$ et al.: Association between $\mathrm{X}$-ray repair cross complementing group 1 codon 399 and 194 polymorphisms and lung cancer risk: a meta-analysis. Cancer letters 285(2), 134-140 (2009).

16. Zhan P, Wang Q, Wei SZ et al.: ERCC2/XPD Lys751GIn and Asp312Asn gene polymorphism and lung cancer risk: a meta-analysis involving 22 case-control studies. J Thorac Oncol 5(9), 1337-1345 (2010).

17. Zhou B, Hu XM, Wu GY: Association between the XPG gene Asp1104His polymorphism and lung cancer risk. Genetics and molecular research : GMR 15(2), (2016).

18. Zienolddiny S, Campa D, Lind $\mathrm{H}$ et al.: Polymorphisms of DNA repair genes and risk of non-small cell lung cancer. Carcinogenesis 27(3), 560-567 (2006).

19. Bei L, Xiao-Dong T, Yu-Fang G, Jian-Ping S, Zhao-Yu Y: DNA repair gene XRCC3 Thr241Met polymorphisms and lung cancer risk: a meta-analysis. Bulletin du cancer 102(4), 332-339 (2015).

20. Xu TP, Shen H, Liu LX, Shu YQ: Association of ERCC1-C118T and -C8092A polymorphisms with lung cancer risk and survival of advanced-stage non-small cell lung cancer patients receiving platinum-based chemotherapy: a pooled analysis based on 39 reports. Gene 526(2), 265-274 (2013).

21. Tan X, Xian L, Chen X et al.: Association between ERCC2 Lys751GIn polymorphism and lung cancer risk: a meta-analysis involving 23,370 subjects. Twin research and human genetics : the official journal of the International Society for Twin Studies 17(2), 99-107 (2014).

22. Shen $\mathrm{M}$, Berndt $\mathrm{SI}$, Rothman $\mathrm{N}$ et al.: Polymorphisms in the DNA nucleotide excision repair genes and lung cancer risk in Xuan Wei, China. International journal of cancer. Journal international du cancer 116(5), 768-773 (2005). 
23. Catana A, Pop M, Hincu BD et al.: The XRCC1 Arg194Trp polymorphism is significantly associated with lung adenocarcinoma: a case-control study in an Eastern European Caucasian group. OncoTargets and therapy 8, 3533-3538 (2015).

24. Wei $\mathrm{Q}$, Shen $\mathrm{H}$, Wang LE et al.: Association between low dietary folate intake and suboptimal cellular DNA repair capacity. Cancer epidemiology, biomarkers \& prevention : a publication of the American Association for Cancer Research, cosponsored by the American Society of Preventive Oncology 12(10), 963-969 (2003).

25. Jacques PF, Bostom AG, Williams RR et al.: Relation between folate status, a common mutation in methylenetetrahydrofolate reductase, and plasma homocysteine concentrations. Circulation 93(1), 7-9 (1996).

26. Hou Z, Matherly LH: Biology of the major facilitative folate transporters SLC19A1 and SLC46A1. Current topics in membranes 73, 175-204 (2014).

27. Huang X, Gao Y, He J et al.: The association between RFC1 G80A polymorphism and cancer susceptibility: Evidence from 33 studies. Journal of Cancer 7(2), 144152 (2016).

28. Shen M, Rothman N, Berndt SI et al:: Polymorphisms in folate metabolic genes and lung cancer risk in Xuan Wei, China. Lung cancer 49(3), 299-309 (2005).

29. Mao R, Fan Y, Jin Y, Bai J, Fu S: Methylenetetrahydrofolate reductase gene polymorphisms and lung cancer: a meta-analysis. Journal of human genetics 53(4), 340-348 (2008).

30. Zhu N, Gong Y, He J, Xia J, Chen X: Influence of methylenetetrahydrofolate reductase C677T polymorphism on the risk of lung cancer and the clinical response to platinum-based chemotherapy for advanced non-small cell lung cancer: an updated meta-analysis. Yonsei medical journal 54(6), 1384-1393 (2013).

31. Liu $\mathrm{H}$, Jin $\mathrm{G}$, Wang $\mathrm{H}$ et al.: Association of polymorphisms in one-carbon metabolizing genes and lung cancer risk: a case-control study in Chinese population. Lung cancer 61(1), 21-29 (2008).

32. Cui Lh YZ, Zhang Tt, Shin Mh, Kim Hn, Choi Js.: Influence of polymorphisms in MTHFR $677 \mathrm{C} \rightarrow$ T, TYMS $3 R \rightarrow 2 R$ and MTR $2756 \mathrm{~A} \rightarrow \mathrm{G}$ on NSCLC risk and response to platinum-based chemotherapy in advanced NSCLC.

Pharmacogenomics. 12(6), 797-808 (2011).

33. Wang Y, Spitz MR, Schabath MB, Ali-Osman F, Mata H, Wu X: Association between glutathione S-transferase $\mathrm{p} 1$ polymorphisms and lung cancer risk in Caucasians: a case-control study. Lung Cancer 40(1), 25-32 (2003).

34. Saarikoski ST, Voho A, Reinikainen M et al.: Combined effect of polymorphic GST genes on individual susceptibility to lung cancer. International Journal of Cancer 77(4), 516-521 (1998). 
35. Ryberg D, Skaug V, Hewer A et al.: Genotypes of glutathione transferase M1 and $\mathrm{P} 1$ and their significance for lung DNA adduct levels and cancer risk. Carcinogenesis 18(7), 1285-1289 (1997).

36. Anttila S, Hirvonen A, Vainio H, Husgafvel-Pursiainen K, Hayes JD, Ketterer B: Immunohistochemical localization of glutathione S-transferases in human lung. Cancer research 53(23), 5643-5648 (1993).

37. Feng X, Zhou HF, Zheng BS, Shi JJ, Luo C, Qin JJ: Association of glutathione Stransferase $\mathrm{P} 1$ gene polymorphism with the histological types of lung cancer: a meta-analysis. Molecular biology reports 40(3), 2439-2447 (2013).

38. Li XM, Yu XW, Yuan Y et al.: Glutathione S-transferase P1, gene-gene interaction, and lung cancer susceptibility in the Chinese population: An updated meta-analysis and review. Journal of cancer research and therapeutics 11(3), 565-570 (2015).

39. Edge Sb BR, Compton Cc, Fritz Ag, Green FI, Trotti a, Editors: AJCC Cancer Staging Manual. 7 ed. Springer-Verlag New York, pp. XV-648 (2010).

40. Jimenez-Varo E, Canadas-Garre M, Henriques $\mathrm{Cl}$, Pinheiro AM, GutierrezPimentel MJ, Calleja-Hernandez MA: Pharmacogenetics role in the safety of acenocoumarol therapy. Thrombosis and haemostasis 112(3), 522-536 (2014).

41. Team RC. R: A language and environment for statistical computing. [Internet]. 2013 Oct. Available from: http://www.r-project.org/.

42. Purcell S, Neale B, Todd-Brown K et al.: PLINK: a toolset for whole-genome association and population-based linkage analysis. American journal of human genetics 81, (2007).

43. De Laat WL, Appeldoorn E, Jaspers NG, Hoeijmakers JH: DNA structural elements required for ERCC1-XPF endonuclease activity. The Journal of biological chemistry 273(14), 7835-7842 (1998).

44. Coin F, Marinoni JC, Rodolfo C, Fribourg S, Pedrini AM, Egly JM: Mutations in the XPD helicase gene result in XP and TTD phenotypes, preventing interaction between XPD and the p44 subunit of TFIIH. Nature genetics 20(2), 184-188 (1998).

45. O'donovan A, Davies AA, Moggs JG, West SC, Wood RD: XPG endonuclease makes the 3 ' incision in human DNA nucleotide excision repair. Nature 371(6496), 432-435 (1994).

46. Shrivastav M, De Haro LP, Nickoloff JA: Regulation of DNA double-strand break repair pathway choice. Cell research 18(1), 134-147 (2008).

47. Singh S: Cytoprotective and regulatory functions of glutathione S-transferases in cancer cell proliferation and cell death. Cancer chemotherapy and pharmacology 75(1), 1-15 (2015). 
Table 1. Clinico-pathologic characteristics of NSCLC cases and controls cases.

\begin{tabular}{|c|c|c|c|c|c|c|c|c|c|}
\hline Chr & SNP & Minor & Mayor & Model & Cases & Controls & $\chi^{2}$ & $p$-value & $p$-value \\
& & Allele & Allele & & & & $\chi^{2}$ & Fisher \\
\hline
\end{tabular}

\begin{tabular}{|c|c|c|c|c|c|c|c|}
\hline & Cases & Controls & $x^{2}$ & $\mathrm{p}$-value & Reference & OR & IC95\% \\
\hline & $n(\%)$ & $n(\%)$ & & & & & \\
\hline \multicolumn{8}{|l|}{ Gender } \\
\hline Female & $46(26.44)$ & $135(45.3)$ & \multirow{2}{*}{15.7488} & \multirow{2}{*}{$7.233 \cdot 10^{-05}$} & \multirow{2}{*}{ Female } & \multirow{2}{*}{2.3} & \multirow{2}{*}{$1.53-3.46$} \\
\hline Male & $128(73.56)$ & $163(54.7)$ & & & & & \\
\hline Previous lung disease & & 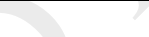 & & & & & \\
\hline YES & $44(25.29)$ & $83(27.85)$ & \multirow{2}{*}{0.2486} & \multirow{2}{*}{0.618} & & & \\
\hline NO & $130(74.71)$ & $215(72.15)$ & & & & & \\
\hline Smoking status & 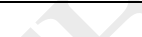 & 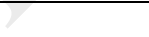 & & & & & \\
\hline Current-Smokers & $85(48.85)$ & $17(6.32)$ & \multirow{3}{*}{123.5797} & \multirow{3}{*}{$<2.2 \cdot 10^{-16}$} & & & \\
\hline Former-smokers & $62(35.63)$ & $107(39.78)$ & & & & & \\
\hline Non-smokers & $27(15.52)$ & $145(53.90)$ & & & & & \\
\hline Age at NSCLC diagnosis & $60.67 \pm 10.58$ & $72.90[67,80]$ & 73.4962 & $<2.2 \cdot 10^{-16}$ & & & \\
\hline \multicolumn{8}{|l|}{ Histology } \\
\hline Adenocarcinoma & $109(62.64)$ & - & \multirow{3}{*}{ - } & \multirow{3}{*}{ - } & \multirow{3}{*}{ - } & \multirow{3}{*}{ - } & \multirow{3}{*}{ - } \\
\hline Squamous cell carcinoma & $61(35.06)$ & - & & & & & \\
\hline Unknown & $4(2.30)$ & - & & & & & \\
\hline \multicolumn{8}{|l|}{ Tumor stage } \\
\hline I, II or IIIA & $55(31.61)$ & - & \multirow{2}{*}{ - } & \multirow{2}{*}{-} & \multirow{2}{*}{ - } & \multirow{2}{*}{ - } & \multirow{2}{*}{-} \\
\hline IIIB or IV & 119 (68.39) & - & & & & & \\
\hline $\begin{array}{l}\text { Qualitative variables: number (perc } \\
\text { Quantitative variables: } \\
\text { Normal distribution: mean } \pm \text { standa } \\
\text { Non-normal distribution: } \mathrm{P}_{50}\left[\mathrm{P}_{25}, \mathrm{P}_{7}\right.\end{array}$ & iation. & & & & & & \\
\hline
\end{tabular}

*Test Wilcoxon

Table 2. Polymorphisms and association with risk of NSCLC 


\begin{tabular}{|c|c|c|c|c|c|c|c|c|c|}
\hline \multirow{5}{*}{1} & \multirow{5}{*}{ rs1801131 } & \multirow{5}{*}{ C } & \multirow{5}{*}{ A } & Genotypic & $13 / 67 / 94$ & $20 / 121 / 157$ & 0.2492 & 0.8829 & 0.8783 \\
\hline & & & & Additive & $93 / 255$ & $161 / 435$ & 0.009469 & 0.9225 & 0.9225 \\
\hline & & & & Allelic & $93 / 255$ & $161 / 435$ & 0.009349 & 0.923 & 0.9395 \\
\hline & & & & Dominant & $80 / 94$ & $141 / 157$ & 0.07904 & 0.7786 & 0.8484 \\
\hline & & & & Recessive & $13 / 161$ & $20 / 278$ & 0.09754 & 0.7548 & 0.8519 \\
\hline \multirow{5}{*}{1} & \multirow{5}{*}{ rs1801133 } & \multirow{5}{*}{$\mathrm{T}$} & \multirow{5}{*}{ C } & Genotypic & $30 / 97 / 47$ & $55 / 138 / 105$ & 4.363 & 0.1129 & 0.1142 \\
\hline & & & & Additive & $157 / 191$ & $248 / 348$ & 1.12 & 0.29 & 0.29 \\
\hline & & & & Allelic & $157 / 191$ & $248 / 348$ & 1.101 & 0.294 & 0.307 \\
\hline & & & & Dominant & $127 / 47$ & $193 / 105$ & 3.403 & 0.06509 & 0.06708 \\
\hline & & & & Recessive & $30 / 144$ & $55 / 243$ & 0.1098 & 0.7403 & 0.8044 \\
\hline \multirow{5}{*}{1} & \multirow{5}{*}{ rs1805087 } & \multirow{5}{*}{ G } & \multirow{5}{*}{ A } & Genotypic & $6 / 48 / 120$ & $7 / 76 / 215$ & 0.8201 & 0.6636 & 0.6592 \\
\hline & & & & Additive & $60 / 288$ & $90 / 506$ & 0.7406 & 0.3895 & 0.3895 \\
\hline & & & & Allelic & $60 / 288$ & $90 / 506$ & 0.7534 & 0.3854 & 0.4067 \\
\hline & & & & Dominant & $54 / 120$ & $83 / 215$ & 0.54 & 0.4624 & 0.464 \\
\hline & & & & Recessive & $6 / 168$ & $7 / 291$ & 0.4956 & 0.4814 & 0.5631 \\
\hline \multirow{5}{*}{11} & \multirow{5}{*}{ rs1695 } & \multirow{5}{*}{ G } & \multirow{5}{*}{ A } & Genotypic & $13 / 81 / 80$ & $34 / 122 / 142$ & 2.581 & 0.2751 & 0.2718 \\
\hline & & & & Additive & $107 / 241$ & $190 / 406$ & 0.1302 & 0.7182 & 0.7182 \\
\hline & & & & Allelic & $107 / 241$ & $190 / 406$ & 0.1306 & 0.7178 & 0.7714 \\
\hline & & & & Dominant & $94 / 80$ & $156 / 142$ & 0.1236 & 0.7252 & 0.7745 \\
\hline & & & & Recessive & $13 / 161$ & $34 / 264$ & 1.9 & 0.1681 & 0.203 \\
\hline \multirow{5}{*}{13} & \multirow{5}{*}{ rs2094258 } & \multirow{5}{*}{ A } & \multirow{5}{*}{ G } & Genotypic & $8 / 59 / 107$ & $11 / 97 / 190$ & 0.375 & 0.829 & 0.8033 \\
\hline & & & & Additive & $75 / 273$ & $119 / 477$ & 0.3423 & 0.5585 & 0.5585 \\
\hline & & & & Allelic & $75 / 273$ & $119 / 477$ & 0.3382 & 0.5609 & 0.5601 \\
\hline & & & & Dominant & $67 / 107$ & $108 / 190$ & 0.2414 & 0.6232 & 0.6231 \\
\hline & & & & Recessive & $8 / 166$ & $11 / 287$ & 0.2336 & 0.6288 & 0.6341 \\
\hline \multirow{3}{*}{13} & \multirow{3}{*}{ rs2296147 } & \multirow{3}{*}{ C } & \multirow{3}{*}{$\mathrm{T}$} & Genotypic & $38 / 84 / 52$ & $64 / 165 / 69$ & 2.996 & 0.2236 & 0.2242 \\
\hline & & & & Additive & $160 / 188$ & $293 / 303$ & 0.9462 & 0.3307 & 0.3307 \\
\hline & & & & Allelic & $160 / 188$ & $293 / 303$ & 0.8924 & 0.3448 & 0.3801 \\
\hline
\end{tabular}




\begin{tabular}{|c|c|c|c|c|c|c|c|c|c|}
\hline & & & & Dominant & $122 / 52$ & $229 / 69$ & 2.611 & 0.1062 & 0.1259 \\
\hline & & & & Recessive & $38 / 136$ & $64 / 234$ & 0.008525 & 0.9264 & 1 \\
\hline \multirow{5}{*}{13} & \multirow{5}{*}{ rs1047768 } & \multirow{5}{*}{$\mathrm{T}$} & \multirow{5}{*}{ C } & Genotypic & $39 / 85 / 50$ & 45/154/99 & 4.175 & 0.124 & 0.13 \\
\hline & & & & Additive & $163 / 185$ & $244 / 352$ & 3.222 & 0.07266 & 0.07266 \\
\hline & & & & Allelic & $163 / 185$ & $244 / 352$ & 3.118 & 0.07744 & 0.08853 \\
\hline & & & & Dominant & $124 / 50$ & 199/99 & 1.023 & 0.3117 & 0.3557 \\
\hline & & & & Recessive & $39 / 135$ & $45 / 253$ & 4.016 & 0.04507 & 0.04711 \\
\hline \multirow{5}{*}{13} & \multirow{5}{*}{ rs17655 } & \multirow{5}{*}{ G } & \multirow{5}{*}{ C } & Genotypic & $14 / 66 / 94$ & $17 / 120 / 161$ & 1.069 & 0.5859 & 0.572 \\
\hline & & & & Additive & $94 / 254$ & $154 / 442$ & 0.1587 & 0.6904 & 0.6904 \\
\hline & & & & Allelic & $94 / 254$ & $154 / 442$ & 0.156 & 0.6929 & 0.702 \\
\hline & & & & Dominant & $80 / 94$ & $137 / 161$ & $6.58 \times 10^{-07}$ & 0.9994 & 1 \\
\hline & & & & Recessive & $14 / 160$ & $17 / 281$ & 0.9813 & 0.3219 & 0.3397 \\
\hline \multirow{5}{*}{13} & \multirow{5}{*}{ rs873601 } & \multirow{5}{*}{ G } & \multirow{5}{*}{ A } & Genotypic & $15 / 59 / 100$ & $23 / 118 / 157$ & 1.522 & 0.4673 & 0.4549 \\
\hline & & & & Additive & $89 / 259$ & $164 / 432$ & 0.4045 & 0.5248 & 0.5248 \\
\hline & & & & Allelic & $89 / 259$ & $164 / 432$ & 0.4224 & 0.5157 & 0.5428 \\
\hline & & & & Dominant & $74 / 100$ & $141 / 157$ & 1.015 & 0.3137 & 0.3387 \\
\hline & & & & Recessive & $15 / 159$ & $23 / 275$ & 0.1209 & 0.7281 & 0.7287 \\
\hline \multirow{5}{*}{14} & \multirow{5}{*}{ rs2236225 } & & \multirow{5}{*}{ C } & Genotypic & $32 / 81 / 61$ & $64 / 137 / 97$ & 0.7285 & 0.6947 & 0.7107 \\
\hline & & & & Additive & $145 / 203$ & $265 / 331$ & 0.6597 & 0.4167 & 0.4167 \\
\hline & & $\mathrm{T}$ & & Allelic & $145 / 203$ & $265 / 331$ & 0.6993 & 0.403 & 0.4147 \\
\hline & & & & Dominant & $113 / 61$ & $201 / 97$ & 0.3101 & 0.5776 & 0.6136 \\
\hline & & & & Recessive & $32 / 142$ & $64 / 234$ & 0.6456 & 0.4217 & 0.4775 \\
\hline \multirow{5}{*}{14} & \multirow{5}{*}{ rs861539 } & \multirow{5}{*}{$\mathrm{T}$} & \multirow{5}{*}{ C } & Genotypic & $16 / 86 / 72$ & $43 / 148 / 107$ & 3.277 & 0.1943 & 0.1924 \\
\hline & & & & Additive & $118 / 230$ & $234 / 362$ & 2.865 & 0.09052 & 0.09052 \\
\hline & & & & Allelic & $118 / 230$ & $234 / 362$ & 2.693 & 0.1008 & 0.1087 \\
\hline & & & & Dominant & $102 / 72$ & $191 / 107$ & 1.398 & 0.2371 & 0.24 \\
\hline & & & & Recessive & $16 / 158$ & $43 / 255$ & 2.752 & 0.09715 & 0.1129 \\
\hline 19 & rs25487 & A & G & Genotypic & $23 / 84 / 67$ & $42 / 131 / 125$ & 0.8301 & 0.6603 & 0.6605 \\
\hline
\end{tabular}




\begin{tabular}{|c|c|c|c|c|c|c|c|c|c|}
\hline & & & & Additive & $130 / 218$ & $215 / 381$ & 0.1531 & 0.6956 & 0.6956 \\
\hline & & & & Allelic & $130 / 218$ & $215 / 381$ & 0.1558 & 0.693 & 0.7262 \\
\hline & & & & Dominant & $107 / 67$ & $173 / 125$ & 0.5389 & 0.4629 & 0.4972 \\
\hline & & & & Recessive & $23 / 151$ & $42 / 256$ & 0.07092 & 0.79 & 0.8901 \\
\hline \multirow{5}{*}{19} & \multirow{5}{*}{ rs1799782 } & \multirow{5}{*}{$\mathrm{T}$} & \multirow{5}{*}{ C } & Genotypic & $1 / 25 / 148$ & $3 / 46 / 249$ & NA & NA & 0.9221 \\
\hline & & & & Additive & $27 / 321$ & $52 / 544$ & 0.2624 & 0.6084 & 0.6084 \\
\hline & & & & Allelic & $27 / 321$ & $52 / 544$ & 0.2675 & 0.605 & 0.6286 \\
\hline & & & & Dominant & $26 / 148$ & $49 / 249$ & NA & NA & 0.6975 \\
\hline & & & & Recessive & $1 / 173$ & $3 / 295$ & NA & NA & 1 \\
\hline \multirow{5}{*}{19} & \multirow{5}{*}{ rs13181 } & \multirow{5}{*}{ G } & \multirow{5}{*}{$\mathrm{T}$} & Genotypic & $30 / 68 / 76$ & $33 / 134 / 131$ & 4.022 & 0.1339 & 0.1389 \\
\hline & & & & Additive & $128 / 220$ & $200 / 396$ & 0.954 & 0.3287 & 0.3287 \\
\hline & & & & Allelic & $128 / 220$ & $200 / 396$ & 1.008 & 0.3155 & 0.322 \\
\hline & & & & Dominant & $98 / 76$ & $167 / 131$ & 0.003537 & 0.9526 & 1 \\
\hline & & & & Recessive & $30 / 144$ & $33 / 265$ & 3.613 & 0.05733 & 0.06804 \\
\hline \multirow{5}{*}{19} & \multirow{5}{*}{ rs238416 } & \multirow{5}{*}{ A } & \multirow{5}{*}{ G } & Genotypic & $25 / 85 / 64$ & $55 / 141 / 102$ & 1.341 & 0.5114 & 0.5273 \\
\hline & & & & Additive & $135 / 213$ & $251 / 345$ & 0.9931 & 0.319 & 0.319 \\
\hline & & & & Allelic & $135 / 213$ & $251 / 345$ & 1.003 & 0.3167 & 0.337 \\
\hline & & & & Dominant & $110 / 64$ & $196 / 102$ & 0.3141 & 0.5752 & 0.6177 \\
\hline & & & & Recessive & $25 / 149$ & $55 / 243$ & 1.305 & 0.2534 & 0.309 \\
\hline \multirow{5}{*}{19} & \multirow{5}{*}{ rs50872 } & \multirow{5}{*}{$\mathrm{T}$} & \multirow{5}{*}{ C } & Genotypic & $6 / 63 / 105$ & 9/92/197 & 1.585 & 0.4526 & 0.462 \\
\hline & & & & Additive & $75 / 273$ & $110 / 486$ & 1.395 & 0.2376 & 0.2376 \\
\hline & & & & Allelic & $75 / 273$ & $110 / 486$ & 1.336 & 0.2477 & 0.2694 \\
\hline & & & & Dominant & $69 / 105$ & $101 / 197$ & 1.583 & 0.2083 & 0.2332 \\
\hline & & & & Recessive & $6 / 168$ & $9 / 289$ & 0.06544 & 0.7981 & 0.7913 \\
\hline \multirow{4}{*}{19} & \multirow{4}{*}{ rs1799793 } & \multirow{4}{*}{ A } & \multirow{4}{*}{ G } & Genotypic & $27 / 69 / 78$ & $32 / 128 / 138$ & 2.346 & 0.3094 & 0.3141 \\
\hline & & & & Additive & $123 / 225$ & $192 / 404$ & 0.9121 & 0.3395 & 0.3395 \\
\hline & & & & Allelic & $123 / 225$ & $192 / 404$ & 0.9681 & 0.3251 & 0.3524 \\
\hline & & & & Dominant & $96 / 78$ & $160 / 138$ & 0.0971 & 0.7553 & 0.7746 \\
\hline
\end{tabular}




\begin{tabular}{|c|c|c|c|c|c|c|c|c|c|}
\hline & & & & Recessive & $27 / 147$ & $32 / 266$ & 2.294 & 0.1299 & 0.1493 \\
\hline \multirow{5}{*}{19} & \multirow{5}{*}{ rs238405 } & \multirow{5}{*}{ A } & \multirow{5}{*}{$\mathrm{T}$} & Genotypic & $38 / 84 / 52$ & 79/137/82 & 1.308 & 0.5199 & 0.5172 \\
\hline & & & & Additive & $160 / 188$ & $295 / 301$ & 1.026 & 0.3111 & 0.3111 \\
\hline & & & & Allelic & $160 / 188$ & $295 / 301$ & 1.09 & 0.2964 & 0.3116 \\
\hline & & & & Dominant & $122 / 52$ & $216 / 82$ & 0.3031 & 0.582 & 0.5979 \\
\hline & & & & Recessive & $38 / 136$ & $79 / 219$ & 1.286 & 0.2569 & 0.2711 \\
\hline \multirow{5}{*}{19} & \multirow{5}{*}{ rs3212986 } & \multirow{5}{*}{$\mathrm{T}$} & \multirow{5}{*}{ G } & Genotypic & $14 / 68 / 92$ & $21 / 117 / 160$ & 0.1625 & 0.9219 & 0.9121 \\
\hline & & & & Additive & $96 / 252$ & $159 / 437$ & 0.0914 & 0.7624 & 0.7624 \\
\hline & & & & Allelic & $96 / 252$ & $159 / 437$ & 0.09195 & 0.7617 & 0.7618 \\
\hline & & & & Dominant & $82 / 92$ & $138 / 160$ & 0.02952 & 0.8636 & 0.9238 \\
\hline & & & & Recessive & $14 / 160$ & $21 / 277$ & 0.1597 & 0.6894 & 0.7177 \\
\hline \multirow{5}{*}{19} & \multirow{5}{*}{ rs11615 } & \multirow{5}{*}{ C } & \multirow{5}{*}{$\mathrm{T}$} & Genotypic & $30 / 85 / 59$ & $47 / 144 / 107$ & 0.2764 & 0.8709 & 0.8709 \\
\hline & & & & Additive & $145 / 203$ & $238 / 358$ & 0.2756 & 0.5996 & 0.5996 \\
\hline & & & & Allelic & $145 / 203$ & $238 / 358$ & 0.2739 & 0.6007 & 0.6307 \\
\hline & & & & Dominant & $115 / 59$ & $191 / 107$ & 0.1923 & 0.661 & 0.6902 \\
\hline & & & & Recessive & $30 / 144$ & $47 / 251$ & 0.1738 & 0.6768 & 0.6995 \\
\hline \multirow{5}{*}{21} & \multirow{5}{*}{ rs1051266 } & \multirow{5}{*}{ A } & \multirow{5}{*}{ G } & Genotypic & $43 / 80 / 51$ & $71 / 162 / 65$ & 4.056 & 0.1316 & 0.1358 \\
\hline & & & & Additive & $166 / 182$ & $304 / 292$ & 0.9854 & 0.3209 & 0.3209 \\
\hline & & & & Allelic & $166 / 182$ & $304 / 292$ & 0.9603 & 0.3271 & 0.3452 \\
\hline & & & & Dominant & $123 / 51$ & $233 / 65$ & 3.332 & 0.06794 & 0.07644 \\
\hline & & & & Recessive & $43 / 131$ & $71 / 227$ & 0.0472 & 0.828 & 0.8246 \\
\hline \multirow{5}{*}{1} & \multirow{5}{*}{ rs1801131 } & \multirow{5}{*}{ C } & \multirow{5}{*}{ A } & Genotypic & $13 / 67 / 94$ & $20 / 121 / 157$ & 0.2492 & 0.8829 & 0.8783 \\
\hline & & & & Additive & $93 / 255$ & $161 / 435$ & 0.009469 & 0.9225 & 0.9225 \\
\hline & & & & Allelic & $93 / 255$ & $161 / 435$ & 0.009349 & 0.923 & 0.9395 \\
\hline & & & & Dominant & $80 / 94$ & $141 / 157$ & 0.07904 & 0.7786 & 0.8484 \\
\hline & & & & Recessive & $13 / 161$ & $20 / 278$ & 0.09754 & 0.7548 & 0.8519 \\
\hline \multirow{2}{*}{1} & \multirow{2}{*}{ rs1801133 } & \multirow{2}{*}{$\mathrm{T}$} & \multirow{2}{*}{ C } & Genotypic & $30 / 97 / 47$ & $55 / 138 / 105$ & 4.363 & 0.1129 & 0.1142 \\
\hline & & & & Additive & $157 / 191$ & $248 / 348$ & 1.12 & 0.29 & 0.29 \\
\hline
\end{tabular}




\begin{tabular}{|c|c|c|c|c|c|c|c|c|c|}
\hline & & & & Allelic & $157 / 191$ & $248 / 348$ & 1.101 & 0.294 & 0.307 \\
\hline & & & & Dominant & $127 / 47$ & $193 / 105$ & 3.403 & 0.06509 & 0.06708 \\
\hline & & & & Recessive & $30 / 144$ & $55 / 243$ & 0.1098 & 0.7403 & 0.8044 \\
\hline \multirow{5}{*}{1} & \multirow{5}{*}{ rs1805087 } & \multirow{5}{*}{ G } & \multirow{5}{*}{ A } & Genotypic & $6 / 48 / 120$ & $7 / 76 / 215$ & 0.8201 & 0.6636 & 0.6592 \\
\hline & & & & Additive & $60 / 288$ & $90 / 506$ & 0.7406 & 0.3895 & 0.3895 \\
\hline & & & & Allelic & $60 / 288$ & $90 / 506$ & 0.7534 & 0.3854 & 0.4067 \\
\hline & & & & Dominant & $54 / 120$ & $83 / 215$ & 0.54 & 0.4624 & 0.464 \\
\hline & & & & Recessive & $6 / 168$ & $7 / 291$ & 0.4956 & 0.4814 & 0.5631 \\
\hline \multirow{5}{*}{11} & \multirow{5}{*}{ rs1695 } & \multirow{5}{*}{ G } & \multirow{5}{*}{$A$} & Genotypic & $13 / 81 / 80$ & $34 / 122 / 142$ & 2.581 & 0.2751 & 0.2718 \\
\hline & & & & Additive & $107 / 241$ & $190 / 406$ & 0.1302 & 0.7182 & 0.7182 \\
\hline & & & & Allelic & $107 / 241$ & $190 / 406$ & 0.1306 & 0.7178 & 0.7714 \\
\hline & & & & Dominant & $94 / 80$ & $156 / 142$ & 0.1236 & 0.7252 & 0.7745 \\
\hline & & & & Recessive & $13 / 161$ & $34 / 264$ & 1.9 & 0.1681 & 0.203 \\
\hline \multirow{5}{*}{13} & \multirow{5}{*}{ rs2094258 } & \multirow{5}{*}{ A } & \multirow{5}{*}{ G } & Genotypic & $8 / 59 / 107$ & $11 / 97 / 190$ & 0.375 & 0.829 & 0.8033 \\
\hline & & & & Additive & $75 / 273$ & $119 / 477$ & 0.3423 & 0.5585 & 0.5585 \\
\hline & & & & Allelic & $75 / 273$ & $119 / 477$ & 0.3382 & 0.5609 & 0.5601 \\
\hline & & & & Dominant & $67 / 107$ & $108 / 190$ & 0.2414 & 0.6232 & 0.6231 \\
\hline & & & & Recessive & $8 / 166$ & $11 / 287$ & 0.2336 & 0.6288 & 0.6341 \\
\hline \multirow{5}{*}{13} & \multirow{5}{*}{ rs2296147 } & \multirow{5}{*}{ C } & \multirow{5}{*}{$\mathrm{T}$} & Genotypic & $38 / 84 / 52$ & $64 / 165 / 69$ & 2.996 & 0.2236 & 0.2242 \\
\hline & & & & Additive & $160 / 188$ & $293 / 303$ & 0.9462 & 0.3307 & 0.3307 \\
\hline & & & & Allelic & $160 / 188$ & $293 / 303$ & 0.8924 & 0.3448 & 0.3801 \\
\hline & & & & Dominant & $122 / 52$ & $229 / 69$ & 2.611 & 0.1062 & 0.1259 \\
\hline & & & & Recessive & $38 / 136$ & $64 / 234$ & 0.008525 & 0.9264 & 1 \\
\hline \multirow{5}{*}{13} & \multirow{5}{*}{ rs1047768 } & \multirow{5}{*}{$\mathrm{T}$} & \multirow{5}{*}{ C } & Genotypic & $39 / 85 / 50$ & 45/154/99 & 4.175 & 0.124 & 0.13 \\
\hline & & & & Additive & $163 / 185$ & $244 / 352$ & 3.222 & 0.07266 & 0.07266 \\
\hline & & & & Allelic & $163 / 185$ & $244 / 352$ & 3.118 & 0.07744 & 0.08853 \\
\hline & & & & Dominant & $124 / 50$ & $199 / 99$ & 1.023 & 0.3117 & 0.3557 \\
\hline & & & & Recessive & $39 / 135$ & $45 / 253$ & 4.016 & 0.04507 & 0.04711 \\
\hline
\end{tabular}




\begin{tabular}{|c|c|c|c|c|c|c|c|c|c|}
\hline \multirow{3}{*}{13} & \multirow{3}{*}{ rs17655 } & \multirow{3}{*}{ G } & \multirow{3}{*}{ C } & Genotypic & $14 / 66 / 94$ & $17 / 120 / 161$ & 1.069 & 0.5859 & 0.572 \\
\hline & & & & Additive & $94 / 254$ & $154 / 442$ & 0.1587 & 0.6904 & 0.6904 \\
\hline & & & & Allelic & $94 / 254$ & $154 / 442$ & 0.156 & 0.6929 & 0.702 \\
\hline \multirow{2}{*}{13} & \multirow{2}{*}{ rs17655 } & \multirow{2}{*}{ G } & \multirow{2}{*}{ C } & Dominant & $80 / 94$ & $137 / 161$ & $6.58 \mathrm{e}-07$ & 0.9994 & 1 \\
\hline & & & & Recessive & $14 / 160$ & $17 / 281$ & 0.9813 & 0.3219 & 0.3397 \\
\hline \multirow{5}{*}{13} & \multirow{5}{*}{ rs873601 } & \multirow{5}{*}{ G } & \multirow{5}{*}{ A } & Genotypic & $15 / 59 / 100$ & $23 / 118 / 157$ & 1.522 & 0.4673 & 0.4549 \\
\hline & & & & Additive & $89 / 259$ & $164 / 432$ & 0.4045 & 0.5248 & 0.5248 \\
\hline & & & & Allelic & $89 / 259$ & $164 / 432$ & 0.4224 & 0.5157 & 0.5428 \\
\hline & & & & Dominant & $74 / 100$ & $141 / 157$ & 1.015 & 0.3137 & 0.3387 \\
\hline & & & & Recessive & $15 / 159$ & $23 / 275$ & 0.1209 & 0.7281 & 0.7287 \\
\hline \multirow{5}{*}{14} & \multirow{5}{*}{ rs2236225 } & \multirow{5}{*}{$\mathrm{T}$} & \multirow{5}{*}{$\mathrm{C}$} & Genotypic & $32 / 81 / 61$ & $64 / 137 / 97$ & 0.7285 & 0.6947 & 0.7107 \\
\hline & & & & Additive & $145 / 203$ & $265 / 331$ & 0.6597 & 0.4167 & 0.4167 \\
\hline & & & & Allelic & $145 / 203$ & $265 / 331$ & 0.6993 & 0.403 & 0.4147 \\
\hline & & & & Dominant & $113 / 61$ & 201/97 & 0.3101 & 0.5776 & 0.6136 \\
\hline & & & & Recessive & $32 / 142$ & $64 / 234$ & 0.6456 & 0.4217 & 0.4775 \\
\hline \multirow{5}{*}{14} & \multirow{5}{*}{ rs861539 } & \multirow{5}{*}{$\mathrm{T}$} & \multirow{5}{*}{$\mathrm{C}$} & Genotypic & $16 / 86 / 72$ & $43 / 148 / 107$ & 3.277 & 0.1943 & 0.1924 \\
\hline & & & & Additive & $118 / 230$ & $234 / 362$ & 2.865 & 0.09052 & 0.09052 \\
\hline & & & & Allelic & $118 / 230$ & $234 / 362$ & 2.693 & 0.1008 & 0.1087 \\
\hline & & & & Dominant & $102 / 72$ & $191 / 107$ & 1.398 & 0.2371 & 0.24 \\
\hline & & & & Recessive & $16 / 158$ & $43 / 255$ & 2.752 & 0.09715 & 0.1129 \\
\hline \multirow{5}{*}{19} & \multirow{5}{*}{ rs25487 } & \multirow{5}{*}{ A } & \multirow{5}{*}{ G } & Genotypic & $23 / 84 / 67$ & $42 / 131 / 125$ & 0.8301 & 0.6603 & 0.6605 \\
\hline & & & & Additive & $130 / 218$ & $215 / 381$ & 0.1531 & 0.6956 & 0.6956 \\
\hline & & & & Allelic & $130 / 218$ & $215 / 381$ & 0.1558 & 0.693 & 0.7262 \\
\hline & & & & Dominant & $107 / 67$ & $173 / 125$ & 0.5389 & 0.4629 & 0.4972 \\
\hline & & & & Recessive & $23 / 151$ & $42 / 256$ & 0.07092 & 0.79 & 0.8901 \\
\hline \multirow{3}{*}{19} & \multirow{3}{*}{ rs1799782 } & \multirow{3}{*}{$\mathrm{T}$} & \multirow{3}{*}{ C } & Genotypic & $1 / 25 / 148$ & $3 / 46 / 249$ & NA & NA & 0.9221 \\
\hline & & & & Additive & $27 / 321$ & $52 / 544$ & 0.2624 & 0.6084 & 0.6084 \\
\hline & & & & Allelic & $27 / 321$ & $52 / 544$ & 0.2675 & 0.605 & 0.6286 \\
\hline
\end{tabular}




\begin{tabular}{|c|c|c|c|c|c|c|c|c|c|}
\hline & & & & Dominant & $26 / 148$ & $49 / 249$ & NA & NA & 0.6975 \\
\hline & & & & Recessive & $1 / 173$ & $3 / 295$ & NA & NA & 1 \\
\hline \multirow{5}{*}{19} & \multirow{5}{*}{ rs13181 } & \multirow{5}{*}{ G } & \multirow{5}{*}{$\mathrm{T}$} & Genotypic & $30 / 68 / 76$ & $33 / 134 / 131$ & 4.022 & 0.1339 & 0.1389 \\
\hline & & & & Additive & $128 / 220$ & $200 / 396$ & 0.954 & 0.3287 & 0.3287 \\
\hline & & & & Allelic & $128 / 220$ & $200 / 396$ & 1.008 & 0.3155 & 0.322 \\
\hline & & & & Dominant & $98 / 76$ & $167 / 131$ & 0.003537 & 0.9526 & 1 \\
\hline & & & & Recessive & $30 / 144$ & $33 / 265$ & 3.613 & 0.05733 & 0.06804 \\
\hline \multirow{5}{*}{19} & \multirow{5}{*}{ rs238416 } & \multirow{5}{*}{ A } & \multirow{5}{*}{ G } & Genotypic & $25 / 85 / 64$ & $55 / 141 / 102$ & 1.341 & 0.5114 & 0.5273 \\
\hline & & & & Additive & $135 / 213$ & $251 / 345$ & 0.9931 & 0.319 & 0.319 \\
\hline & & & & Allelic & $135 / 213$ & $251 / 345$ & 1.003 & 0.3167 & 0.337 \\
\hline & & & & Dominant & $110 / 64$ & $196 / 102$ & 0.3141 & 0.5752 & 0.6177 \\
\hline & & & & Recessive & $25 / 149$ & $55 / 243$ & 1.305 & 0.2534 & 0.309 \\
\hline \multirow{5}{*}{19} & \multirow{5}{*}{ rs50872 } & \multirow{5}{*}{$\mathrm{T}$} & \multirow{5}{*}{ C } & Genotypic & $6 / 63 / 105$ & 9/92/197 & 1.585 & 0.4526 & 0.462 \\
\hline & & & & Additive & $75 / 273$ & $110 / 486$ & 1.395 & 0.2376 & 0.2376 \\
\hline & & & & Allelic & $75 / 273$ & $110 / 486$ & 1.336 & 0.2477 & 0.2694 \\
\hline & & & & Dominant & $69 / 105$ & $101 / 197$ & 1.583 & 0.2083 & 0.2332 \\
\hline & & & & Recessive & $6 / 168$ & $9 / 289$ & 0.06544 & 0.7981 & 0.7913 \\
\hline \multirow{5}{*}{19} & \multirow{5}{*}{ rs1799793 } & \multirow{5}{*}{ A } & \multirow{5}{*}{ G } & Genotypic & $27 / 69 / 78$ & $32 / 128 / 138$ & 2.346 & 0.3094 & 0.3141 \\
\hline & & & & Additive & $123 / 225$ & $192 / 404$ & 0.9121 & 0.3395 & 0.3395 \\
\hline & & & & Allelic & $123 / 225$ & $192 / 404$ & 0.9681 & 0.3251 & 0.3524 \\
\hline & & & & Dominant & $96 / 78$ & $160 / 138$ & 0.0971 & 0.7553 & 0.7746 \\
\hline & & & & Recessive & $27 / 147$ & $32 / 266$ & 2.294 & 0.1299 & 0.1493 \\
\hline \multirow{5}{*}{19} & \multirow{5}{*}{ rs238405 } & \multirow{5}{*}{ A } & \multirow{5}{*}{$\mathrm{T}$} & Genotypic & $38 / 84 / 52$ & $79 / 137 / 82$ & 1.308 & 0.5199 & 0.5172 \\
\hline & & & & Additive & $160 / 188$ & $295 / 301$ & 1.026 & 0.3111 & 0.3111 \\
\hline & & & & Allelic & $160 / 188$ & $295 / 301$ & 1.09 & 0.2964 & 0.3116 \\
\hline & & & & Dominant & $122 / 52$ & $216 / 82$ & 0.3031 & 0.582 & 0.5979 \\
\hline & & & & Recessive & $38 / 136$ & $79 / 219$ & 1.286 & 0.2569 & 0.2711 \\
\hline 19 & rs3212986 & $\mathrm{T}$ & G & Genotypic & $14 / 68 / 92$ & $21 / 117 / 160$ & 0.1625 & 0.9219 & 0.9121 \\
\hline
\end{tabular}




\begin{tabular}{|c|c|c|c|c|c|c|c|c|c|}
\hline & & & & Additive & $96 / 252$ & $159 / 437$ & 0.0914 & 0.7624 & 0.7624 \\
\hline & & & & Allelic & $96 / 252$ & $159 / 437$ & 0.09195 & 0.7617 & 0.7618 \\
\hline & & & & Dominant & $82 / 92$ & $138 / 160$ & 0.02952 & 0.8636 & 0.9238 \\
\hline & & & & Recessive & $14 / 160$ & $21 / 277$ & 0.1597 & 0.6894 & 0.7177 \\
\hline \multirow{5}{*}{19} & \multirow{5}{*}{ rs11615 } & \multirow{5}{*}{ C } & \multirow{5}{*}{$\mathrm{T}$} & Genotypic & $30 / 85 / 59$ & $47 / 144 / 107$ & 0.2764 & 0.8709 & 0.8709 \\
\hline & & & & Additive & $145 / 203$ & $238 / 358$ & 0.2756 & 0.5996 & 0.5996 \\
\hline & & & & Allelic & $145 / 203$ & $238 / 358$ & 0.2739 & 0.6007 & 0.6307 \\
\hline & & & & Dominant & $115 / 59$ & $191 / 107$ & 0.1923 & 0.661 & 0.6902 \\
\hline & & & & Recessive & $30 / 144$ & $47 / 251$ & 0.1738 & 0.6768 & 0.6995 \\
\hline \multirow{5}{*}{21} & \multirow{5}{*}{ rs1051266 } & \multirow{5}{*}{ A } & \multirow{5}{*}{ G } & Genotypic & $43 / 80 / 51$ & $71 / 162 / 65$ & 4.056 & 0.1316 & 0.1358 \\
\hline & & & & Additive & $166 / 182$ & $304 / 292$ & 0.9854 & 0.3209 & 0.3209 \\
\hline & & & & Allelic & $166 / 182$ & $304 / 292$ & 0.9603 & 0.3271 & 0.3452 \\
\hline & & & & Dominant & $123 / 51$ & $233 / 65$ & 3.332 & 0.06794 & 0.07644 \\
\hline & & & & Recessive & $43 / 131$ & $71 / 227$ & 0.0472 & 0.828 & 0.8246 \\
\hline
\end{tabular}

Chr: chromosome; NA: not applicable

Table 3. Permutation analysis

\begin{tabular}{|l|l|l|l|l|l|l|l|l|}
\hline \multirow{2}{*}{ SNP } & \multicolumn{2}{|c|}{ Genotypic } & \multicolumn{2}{c|}{ Additive } & \multicolumn{2}{c|}{ Recessive } & \multicolumn{2}{c|}{ Dominant } \\
\cline { 2 - 9 } & EMP1 & EMP2 & EMP1 & EMP2 & EMP1 & EMP2 & EMP1 & EMP2 \\
\hline rs1801131 & 0.8774 & 1 & 0.9324 & 1 & 0.8502 & 1 & 0.8478 & 1 \\
\hline rs1801133 & 0.1133 & 0.8579 & 0.2846 & 0.9973 & 0.8046 & 1 & 0.06727 & 0.6692 \\
\hline rs1805087 & 0.3312 & 1 & 0.4109 & 0.9998 & 0.3171 & 1 & 0.2832 & 1 \\
\hline rs1695 & 0.2744 & 0.9942 & 0.7636 & 1 & 0.2045 & 0.9548 & 0.7743 & 1 \\
\hline rs2094258 & 0.7184 & 1 & 0.5978 & 1 & 0.7013 & 1 & 0.6119 & 1 \\
\hline rs2296147 & 0.2274 & 0.9833 & 0.364 & 0.9991 & 1 & 1 & 0.1275 & 0.8479 \\
\hline
\end{tabular}




\begin{tabular}{|l|l|l|l|l|l|l|l|l|}
\hline rs1047768 & 0.1271 & 0.8826 & 0.08115 & 0.7392 & 0.04669 & 0.517 & 0.3549 & 0.9979 \\
\hline
\end{tabular}

\begin{tabular}{|l|l|l|l|}
\hline & Genotypic & Dominant & Recessive \\
\hline
\end{tabular}

\begin{tabular}{|l|l|l|l|l|l|l|l|l|}
\hline rs17655 & 0.5838 & 1 & 0.6915 & 1 & 0.3355 & 0.9984 & 0.9978 & 1 \\
\hline rs873601 & 0.4638 & 1 & 0.5174 & 1 & 0.8598 & 1 & 0.3385 & 0.998 \\
\hline rs2236225 & 0.7126 & 1 & 0.4227 & 0.9999 & 0.4763 & 0.9999 & 0.6155 & 1 \\
\hline rs861539 & 0.1923 & 0.9715 & 0.08657 & 0.8038 & 0.1113 & 0.8246 & 0.2397 & 0.9878 \\
\hline rs25487 & 0.655 & 1 & 0.7299 & 1 & 0.8903 & 1 & 0.4972 & 1 \\
\hline rs1799782 & 1 & 1 & 0.6322 & 1 & 1 & 1 & 1 & 1 \\
\hline rs13181 & 0.1369 & 0.904 & 0.3173 & 0.9989 & 0.06758 & 0.6392 & 1 & 1 \\
\hline rs238416 & 0.5175 & 1 & 0.3405 & 0.9985 & 0.3089 & 0.9908 & 0.6167 & 1 \\
\hline rs50872 & 0.2754 & 0.9999 & 0.2372 & 0.9912 & 0.7015 & 1 & 0.1625 & 0.9766 \\
\hline rs1799793 & 0.3097 & 0.9974 & 0.3668 & 0.9992 & 0.1493 & 0.8963 & 0.773 & 1 \\
\hline rs238405 & 0.5193 & 1 & 0.3182 & 0.9981 & 0.2705 & 0.9913 & 0.598 & 1 \\
\hline rs3212986 & 0.9327 & 1 & 0.7831 & 1 & 0.7188 & 1 & 0.9228 & 1 \\
\hline rs11615 & 0.8629 & 1 & 0.6151 & 1 & 0.7008 & 1 & 0.6922 & 1 \\
\hline rs1051266 & 0.1349 & 0.8991 & 0.3411 & 0.9988 & 0.9117 & 1 & 0.07669 & 0.7009 \\
\hline
\end{tabular}

EMP1: point-wise empirical p-value obtained by permutation; EMP2: empirical p-value that controls for multiple SNPs 


\begin{tabular}{|c|c|c|c|c|c|c|c|c|c|c|c|c|c|}
\hline & \multicolumn{3}{|c|}{ TT vs CC } & \multicolumn{3}{|c|}{$\mathrm{CT}$ vs $\mathrm{CC}$} & \multicolumn{3}{|c|}{ T- vs CC } & \multicolumn{3}{|c|}{ TT vs C- } & \\
\hline & $p$-value & OR & $\mathrm{Cl} 95 \%$ & $\mathrm{p}$-value & OR & IC95\% & $p$-value & OR & IC95\% & $p$-value & OR & IC95\% & $p-$ \\
\hline Age & & & & & & & & & & & & & \\
\hline$\leq 60$ & $<0.001$ & 4.85 & $2.80-8.54$ & $<0.001$ & 4.85 & $2.80-8.54$ & $<0.001$ & 4.88 & $2.83-8.59$ & $<0.001$ & 4.84 & $2.80-8.53$ & $<0$ \\
\hline Smoking status & & & & & & & & & & & & & \\
\hline Current-Smokers & $<0.001$ & 6.52 & $3.52-12.59$ & $<0.001$ & 6.52 & $3.52-12.59$ & $<0.001$ & 6.54 & $3.53-12.60$ & $<0.001$ & 6.49 & $3.50-12.52$ & $<0$ \\
\hline Non-Smokers & $<0.001$ & 0.31 & $0.18-0.53$ & $<0.001$ & 0.31 & $0.18-0.53$ & $<0.001$ & 0.31 & $0.18-0.53$ & $<0.001$ & 0.31 & $0.18-0.53$ & $<0$ \\
\hline ERCC5 rs1047768 & 0.549 & 1.23 & $0.62-2.46$ & 0.616 & 0.87 & $0.51-1.49$ & 0.859 & 0.95 & $0.58-1.59$ & 0.053 & 1.34 & $0.73-2.46$ & 0. \\
\hline
\end{tabular}

Table 4. Influence of clinical characteristic and ERCC5 rs1047768 gene polymorphisms on risk of NSCLC 